\title{
Pocahontas and La Malinche: Mirror Images and Antithetical Archetypes
}

\author{
Amani Khelifa*
}

\begin{abstract}
This paper compares and contrasts two Indigenous figures in Mexican history and American history. La Malinche aided conquistador Hernan Cortés during his conquest of Tenochtitlan in the sixteenth century in a way similar to Pocahontas who 'rescued' Capt. John Smith the following century. Both women are among the earliest Indigenous figures to become mythologized in their respective nations' history, yet the legacy they left behind is different; La Malinche's legacy is more contentious than Pocahontas's. This paper explores the similarities their stories share and the role they play as mediators, mothers, and symbolic figures. It includes a careful study of the many ways Pocahontas and La Malinche have been remembered since, from artistic portrayals to comparisons with biblical figures. Finally, the paper analyzes the nuances in each of their legacies and proposes one way of interpreting why the two figures have come to be regarded differently over time.
\end{abstract}

Keywords: Pocahontas, La Malinche, Indigenous women, native-newcomer history, Mexican history, American history

At a first-glance of Native-newcomer encounters, few figures are as captivating, as mysterious and as misunderstood as the Indigenous woman. Two particularly well-known cases can be found in La Malinche and Pocahontas. The former was present during the conquest of Aztec Mexico by the Spanish in the early sixteenth century, while the latter witnessed the first attempts at English colonization in America and the founding of the first colony at Jamestown, Virginia a century later. La Malinche and Pocahontas each played similar roles in their respective communities in the unfolding of Native-newcomer relations as intermediaries, mothers, and symbolic figures. Still, they remain distinct and perhaps even opposing figures in the national memories of Mexico and America because of the outcome of the events in which they were involved.

This paper builds on a variety of primary and secondary sources. Some notes should be made about the scholarship before scrutinizing the historic images of La Malinche and Pocahontas. It is important to recognize that the women concerned have left behind no records themselves and the primary documents about these figures in particular should be studied with a somewhat

*Department of History, College of Arts and Science, University of Saskatchewan, Saskatoon, SK, Canada

Correspondence: amko86@mail.usask.ca

University of Saskatchewan Undergraduate Research Journal 
skeptical eye. The primary sources are exclusively dominated by European, male authors (Hernan Cortés, Bernal Díaz del Castillo, and John Smith) ${ }^{1}$ and in most cases they were created years, if not decades, after the events they discuss actually took place. In fact, only Hernan Cortés' letters are primary sources in the truest sense. John Smith's Generall Historie was published more than fifteen years after his first encounter with Pocahontas and Bernal Díaz del Castillo's Historia verdadera was first published more than forty-five years following the conquest. As such, their accounts reflect their responses to events in the intervening years at least as much as they are a representation of their genuine memory of the encounters.

Likewise, both of these Native American women have come to be known by multiple names. Pocahontas was born Matoaka, a personal name used only by her parents, while she was known as Amonute to the rest of her community. Pocahontas was actually a nickname she received when she was older and implied she was a playful type. ${ }^{2}$ Later, after her marriage to an Englishman, she was renamed Rebecca.

La Malinche was known by as many names. Born Malinal, her community would come to know her as Malintzin, with the -tzin being an honorific suffix, illustrating that she was addressed with respect during her life. She was baptized Marina and earned the deferential title Doña soon after. The name La Malinche seems to be an Aztec derivation of Malintzin. ${ }^{3}$

In this paper, the women will be called by their most well known names, La Malinche and Pocahontas, while bearing in mind that these other names and nicknames can provide us with insight into who these women were and who gave them their names and titles. Their stories as well their names have been liberally passed on from male author to male author with little input from female commentators until recently. Even fewer of these commentators are Indigenous. This is

\footnotetext{
${ }^{1}$ Sandra M. Cypess, “'Mother' Malinche and Allegories of Gender, Ethnicity and National Identity in Mexico," in Feminism, Nation, and Myth: La Malinche, ed. Amanda Harris and Ronaldo Romero (Houston: Arte Publico Press, 2005), 15.

2 Helen Rountree, Pocahontas, Powhatan, and Opechancanough: Three Indian Lives Changed by Jamestown (Charlottesville: University of Virginia Press, 2005), 37-38.

${ }^{3}$ Cordelia Candelaria, "La Malinche: A Feminist

Prototype," Frontiers: A Journal of Women Studies 5, 2 (1980): 2.
}

especially true of the earliest sources, but does not exclude current trends in the research.

\section{La Malinche and the Conquest of Mexico}

Famous primarily for her role as Cortés' interpreter during the Spanish conquest of Aztec Mexico, La Malinche was born around the year 1502 in the pre-Columbian Mexican province of Coatzacoalos. ${ }^{4}$ She was born into a noble family, likely as the daughter of a cacique, an Aztec chief, due to the fact that she was bilingual in Nahuatl and Mayan. As an adolescent, she eventually found herself in the home of a Tabascan cacique, but historians are divided as to how this happened. One theory advances that she was kidnapped by traveling merchants who took her to Tabasco ${ }^{5}$ while another claims she was sold into slavery by her mother in order for the family inheritance to pass to her half-brother. ${ }^{6}$ Regardless of how she got to be among the Tabascan people, it was in Tabasco where Hernan Cortés met La Malinche when she was given to him as a gift along with a group of twenty Mayan women. ${ }^{7}$ Shortly thereafter, she was baptized and given her Christian name, Doña Marina.

According to Bernal Díaz del Castillo, a fellow conquistador who participated as a soldier in the conquest, Doña Marina was beautiful, intelligent, "an excellent woman and good interpreter." ${ }^{8} \mathrm{He}$ also describes her role as integral not only to their political success in taking over Tenochtitlan, but also to the spread of Christianity. Significantly, del Castillo's account of La Malinche is the most comprehensive primary text we have, while

\footnotetext{
${ }^{4}$ Ibid.

${ }^{5}$ Frances Karttunen, "Rethinking La Malinche,"

in Indian Women of Early Mexico, ed. Susan

Schroeder, Stephanie Wood and Robert Haskett (Norman: University of Oklahoma Press, 2008), 299.

${ }^{6}$ Clara S. Kidwell, "Indian Women as Cultural Mediators," Ethnohistory 39, 2 (1992): 99; Candelaria, "A Feminist Prototype," 2; Kristina Downs, "Mirrored Archetypes: The Contrasting Cultural Roles of La Malinche and Pocahontas," Western Folklore 67, 4 (2008): 406.

7 ] Bernal Díaz del Castillo, The Discovery and

Conquest of Mexico, 1517-1521, trans. A. P. Maudsley (New York: Noonday Press, 1965), 62. 8 Ibid.
} 
Hernan Cortés himself scarcely mentioned her in any of his writings. In fact, he only included her in two of his letters to Emperor Carlos V, and even so, she is mentioned only in passing as "[his] interpreter, who is an Indian woman from Putunchan." ${ }^{\prime 9}$ Cortés's letters were written to the Emperor with certain goals in mind - namely, to secure support for his project. Such goals may have influenced the information he decided to include or omit about La Malinche. Consquently, the lack of primary sources combined with the fact that both are written by conquistadors necessitates a level of critical judgement when we read that, for instance, La Malinche gave a speech to her relatives expressing her gratitude for being Christian, bearing Cortés's son, and marrying Jaramillo. ${ }^{10}$

As an interpreter, La Malinche initially was involved in a triangular chain of interpretation between the Indigenous Americans and Spanish. She would translate from Nahuatl to Mayan and Jeronimo de Aguilar, a Spaniard who was shipwrecked from a previous expedition, would then translate from Mayan to Spanish. ${ }^{11}$ Considering the inherent difficulties and loss of meaning in a single cycle of translation, it is hard to believe that anything was ever communicated at all. After spending some years with Cortés's expedition, however, La Malinche eventually learned Spanish and soon became the sole interpreter Cortés required. ${ }^{12}$ Her role as interpreter, in combination with her knowledge of the land and customs, quickly made her an invaluable asset to the conquistador.

La Malinche's aid and assistance did not stop there. Del Castillo does not doubt that she was imperative to the success of the Spanish Conquest because her role extended beyond translation and interpretation. $^{13}$ She eventually became an indispensable advisor to Cortés and was responsible for gathering information without which the Spaniards' conquest would have been seriously impeded. For instance, during their quest to reach Tenochtitlan, Cortés and his men

\footnotetext{
${ }^{9}$ Hernan Cortés, Hernan Cortés to Emperor Carlos V., in Hernan Cortés: Letters from Mexico, trans. and ed. Anthony Pagden (New Haven and London: Yale University Press, 1986): 72-74. ${ }^{10}$ Díaz del Castillo, 68.

${ }^{11}$ Clara S. Kidwell, "What Would Pocahontas

Think Now? Women and Cultural Persistence," Callaloo 39, 2 (1992): 152.

${ }^{12}$ Candelaria, "A Feminist Prototype," 3.

13 Díaz del Castillo, 68.
}

intended to pass through Cholula but La Malinche, with the help of her connections, discovered a plot to resist their advance. ${ }^{14}$ Additionally, in her encounter with Emperor Moctezuma after arriving in Tenochtitlan, her eloquent commentary on behalf of the Spanish is thought to have prevented an earlier eruption of bloodshed. ${ }^{15}$

To add to the crucial and singular part La Malinche played in assisting Cortés in the conquest, she bore him a son, Martin, for whose legitimation Cortés later succeeded in petitioning the Spanish courts. ${ }^{16}$ La Malinche's role as Martin's mother will become important in the discussion of the symbolism surrounding her story. La Malinche did not live long after these pivotal events. Cortés arranged her marriage to Juan Jaramillo, a nobleman and one of his soldiers with whom she had a daughter. ${ }^{17}$ She died soon after, under the age of thirty, in the approximate year of 1527, most likely of the smallpox that was rampant in that period. ${ }^{18}$ Despite living such a short life, the contentious legacy La Malinche left behind is a long and intricate one.

\section{La Malinche: Remembered, Rethought, Reinvented}

Perhaps the most popular representation of $\mathrm{La}$ Malinche in the national memory of Mexicans is of her as a traitor to the Indigenous Aztec people both by being complicit with the Spanish cause and through her sexual relationship with Cortés, the alleged enemy from this point-of-view. ${ }^{19}$ In fact, today "malinchista" is used in Mexican and Chicano culture to mean "traitor." ${ }^{20}$ Octavio Paz also famously labelled her with the derogatory la

\footnotetext{
${ }^{14}$ Frances Karttunen, "Rethinking La Malinche," in Indian Women of Early Mexico, ed. Susan Schroeder, Stephanie Wood and Robert Haskett (Norman: University of Oklahoma Press, 2008), 303-304.

${ }^{15}$ Candelaria, "A Feminist Prototype," 4.

${ }^{16}$ Karttunen, "Rethinking La Malinche," 308.

17 Ibid, 308-309

${ }^{18}$ Candelaria, "A Feminist Prototype," 3.

${ }^{19}$ Cypess, “'Mother' Malinche," 14-15; Downs, "Mirrored Archetypes," 403.

20 Pamela Scully, "Malintzin, Pocahontas, and Krotoa: Indigenous Women and Myth Models of the Atlantic World," Journal of Colonialism and Colonial History 6, 3 (2005): paragraph 7; Downs, "Mirrored Archetypes," 407.
} 
chingada, signifying a violated woman, ${ }^{21}$ and her name has become associated with promiscuous women. $^{22}$

Furthermore, La Malinche has also been compared and contrasted with biblical figures, indicating that how she is remembered has been decided through a Eurocentric and patriarchal lens. ${ }^{23}$ In particular, she has been contrasted with the Virgin of Guadalupe, who is portrayed as her polar opposite. Everything that she is - pure, good, selfless, and honest - La Malinche is not, and vice versa. ${ }^{24}$ Meanwhile, La Malinche has been described as a "Mexican Eve" figure; her actions constituted the national sin that led to the future subjugation of her people. ${ }^{25}$

La Malinche has been constructed in a more positive image as a symbolic mother figure. Her relationship with Cortés led to one of the first documented births of a mestizo and therefore metaphorically gave birth to the mestizo nation of Mexico. ${ }^{26}$ The symbol of motherhood is significant in shaping a national Mexican identity, specifically when we acknowledge the emphasis placed on the key position of women as mothers. ${ }^{27}$ There is a tension, then, in the relationship between the people of Mexico, a country that largely considers itself a mestizo nation, and their mother who brought them about as a population, albeit through an act of perceived betrayal.

There is a plethora of ways in which La Malinche has been understood and recreated since the events she took part in; the list of portrayals elucidated here are by no means exhaustive. Yet it remains necessary to be critical and curious when considering these various categorizations, for they tell us about who La Malinche really was, as well as what she has come to represent and why. Issues around how La Malinche has been rethought are addressed more extensively in the final section.

\footnotetext{
${ }^{21}$ Kristina Downs, "Mirrored Archetypes," 410.

22 Ibid, 408.

${ }^{23}$ Cypess, “'Mother' Malinche," 15.

24 Ibid, 16; Downs, "Mirrored Archetypes," 403.

${ }^{25}$ Kristina Downs, "Mirrored Archetypes," 411-

412.

${ }^{26}$ Kidwell, "Women and Cultural Persistence," 152.

${ }^{27}$ Cypess, “'Mother' Malinche," 15.
}

\section{Pochahontas and the Jamestown Colony}

Pocahontas, or Amonute as she was known in the early years of her life, ${ }^{28}$ can be said to be La Malinche's equivalent in American history. Though she has come to signify different values and be represented in starkly different ways, she, like La Malinche, occupies a unique place in the historic narrative and memory of the United States.

As with La Malinche, Pocahontas was born into nobility, a daughter of the Powhatan chief, in 1596 and enjoyed the rights and privileges that came with such a status. Pocahontas's father enjoyed a unique kind of leadership as manatowick (paramount chief) since he presided over other chiefs and collected tribute from a number of other groups. ${ }^{29}$

Pocahontas was around the age of eleven when the famous rescue of John Smith occurred in 1607. Historians recognize that the popularized story of this 'rescue' was, in truth, nothing at all like what has been portrayed in the Disney movie and what John Smith himself wrote many years later in his Generall Historie of Virginia. Smith's version of the story follows:

Two great stones were brought before Powhatan: then as many as could layd hands on him, dragged him to them, and thereon laid his head, and being ready with their clubs, to beate out his braines, Pocahontas the Kings dearest daughter, when no intreaty could prevaile, got his head in her armes, and laid her owne upon his to save him from death. ${ }^{30}$

As tempting as it may be to accept this dramatic account, Pocahontas's actions were more likely part of a ritual to adopt him or initiate him as a member of the Indigenous Virginians. Even then, it was not likely her choice or her idea to adopt

\footnotetext{
${ }^{28}$ Camilla Townsend, Pocahontas and the Powhatan Dilemma (New York: Hill and Wang, 2004), 13.

${ }^{29}$ Rountree, Pocahontas, Powhatan, and Opechancanough, 16.

${ }^{30}$ John Smith, The Generall Historie of Virginia, New England, and the Summer Isles (London: I.D. and I.H., 1632): 49.
} 
him for the diplomatic and political reasons that her father and his advisors had in mind. ${ }^{31}$ Regardless of Pocahontas's possible personal convictions on this matter, if she held any convictions at all, the ceremony certainly marked the point of more frequent exchanges between the colonists and Indigenous people. What followed was a period of concerted efforts at cooperation, with the Indigenous populations expecting to benefit from the goods and weapons they were to receive as tribute from the colonists and the colonists believing they had secured a method of obtaining food. It is not surprising that a relationship begun on such mutually misunderstood terms would eventually break down after compounded misapprehensions.

Soon hostilities followed in the wake of this "creaky alliance." ${ }^{32}$ Several years after, the tensions had escalated to a point that the two peoples, Pocahontas's and John Smith's, were in effect waging war. ${ }^{33}$ In 1613, she was captured by the English and held hostage in the hopes of securing weapons that Powhatan had taken. ${ }^{34}$ Pocahontas had a partner who was killed in the event and a child who remained with relatives after her capture. ${ }^{35}$ In a significant turn of events, her father refused to ransom her, ${ }^{36}$ prolonging her stay in Jamestown and giving way to her marriage to John Rolfe, the birth of their son, and her conversion to Christianity whereupon she was baptized and named Rebecca. In recent years, evidence has cast doubt on the authenticity of Pocahontas's 'marriage:' oral histories describe her relationship with Rolfe as coercive rather than consensual, and there is some discussion around research suggesting she was repeatedly raped. ${ }^{37}$ Whatever direction these findings take, they serve as a crucial reminder that, as alluded to in the beginning of the article, the Pocahontas story was fundamentally out of Pocahontas's own grasp, or any Indigenous person's grasp for that matter. Implications of this alienation will be discussed more fully in the final section.

31 Townsend, Powhatan Dilemma, 52-59.

32 Rountree, Pocahontas, Powhatan, and

Opechancanough, 86.

33 Townsend, Powhatan Dilemma, 96.

${ }^{34}$ Kidwell, "Cultural Mediators," 100.

35 Rebecca Mark, "Pocahontas Fever," Ersatz

America: Hidden Traces, Graphic Texts and the

Meaning of Democracy, (Charlottesville:

University of Virginia Press, 2014), 52.

36 Kristina Downs, “Mirrored Archetypes," 398.

37 Mark, "Pocahontas Fever," 70-72.
Notably, in a visit she made to London as Lady Rebecca, John Smith and Pocahontas were reunited, yet this reunion had no undertones of passion and love as the myths would have us imagine. On the contrary, Pocahontas's words to Smith expressed anger, sorrow, and even a hint of betrayal and cynicism. By asking him to act as her adopted father while she was in his land, we can understand that the relationship between them was, from her perspective, supposed to be one of kinship and not romance. Her people had treated him as one of their own when he was the foreigner in Virginia and it was now Smith's turn to do the same for her. The relationship begun by the ritual and 'rescue' was sought for reasons of diplomacy and political advantage, reasons that John Smith did not fully understand. ${ }^{38}$ Just before her scheduled voyage back to Virginia from this trip to England, Pocahontas, in her early twenties, fell ill and died. ${ }^{39}$

\section{Pocahontas in Myth and Memory}

Before providing a brief overview of Pocahontas's historiographical trajectory, it would be appropriate to briefly discuss the version of Pocahontas most of us are likely to be familiar with: Disney's Pocahontas. Much debate has been generated on the topic of Pocahontas's portrayal in the 1995 film, including the not-so-subtle reinforcement of stereotypes of Indigenous peoples. Such stereotypes range from their alleged passivity and the 'empty land' myth ${ }^{40}$ to the myth of Indigenous desire to be colonized, typified in their tendency to be "sexually available. ${ }^{.41}$ Cultural critic Ziauddin Sardar puts it nicely, describing the characters in Pocahontas from Pocahontas herself to Powhatan to John Smith - as constituting a "neatly assembled cast of stereotypes." ${ }^{42}$ That Disney's Pocahontas serves to make the conventional and utterly decontextualized perceptions of the historical woman much more enduring and engrained in public consciousness is perhaps the most detrimental aspect of Pocahontas. It supplies a rendition of Pocahontas for mass consumption one of her as the 'Indian princess', the 'lover' and

\footnotetext{
38 Townsend, Powhatan Dilemma, 154-156.

39 lbid, 157.

${ }^{40}$ Ziauddin Sardar, "Walt Disney and the Double Victimisation of Pocahontas," Third Text 10, 37 (1996): 19.

41 lbid, 18

42 lbid, 17
} 
'protector' of the white man - while advertising it as an authentic step in the direction of multiculturalism, as a remark from Vice Chairman of the company, Roy Disney, suggests:

Pocahontas was a story that appealed to us because it was basically a story about people getting along together in the world. Even though their cultures are very, very different, they have to live on the same land, and that seemed like an enormously appropriate kind of story to tell and one which is particularly applicable to lots of places in the world today. ${ }^{43}$

In short, Pocahontas is little more than "polemic propaganda masquerading as history. ${ }^{144}$

Turning from the Pocahontas of Hollywood to the Pocahontas of literature, a different set of problems is to be found. Most of what we know of Pocahontas is from sources reconstructing her story after her death, and just as with La Malinche, we have no information about her from sources she created or contributed to herself. Nevertheless, plenty has been said on her behalf. One noteworthy difference between the two women is that popular representations of Pocahontas are generally much more positive than those of La Malinche. Just as with La Malinche, Pocahontas has been compared with women of the Bible as well, supporting the argument that the images of these early Indigenous figures have been constructed largely from a Eurocentric point-of-view. ${ }^{45}$ Specifically, Pocahontas is compared positively to the Virgin Mary, as opposed to the negative comparison that has been made between La Malinche and the Virgin of Guadalupe. Historian Rayna Green has extensively studied Pocahontas and her various representations, a phenomenon she calls the "Pocahontas perplex," with a special focus on the "Virgin-Whore paradox" and the "PrincessSquaw" binary. ${ }^{46}$ According to Green, female Indigenous figures historically have been

${ }^{43}$ Quoted by Sardar in The Making of Pocahontas, dir. By Dan Booth, Walt Disney Corporation, 1995.

${ }^{44}$ Ziauddin Sardar, "Walt Disney and the Double Victimisation of Pocahontas," Third Text 10, 37 (1996) 17.

${ }^{45}$ Cypess, "'Mother' Malinche," 15.

${ }^{46}$ Rayna Green, "The Pocahontas Perplex: The Image of Indian Women in American Culture," The Massachusetts Review 16, 4 (1975): 703. portrayed in one of two ways: either positively, as virgins or princesses, or negatively, in the form of 'barbaric whores' or 'squaws.' Both these negative and positive binaries have been constructed after the fact, mostly by European men, ${ }^{47}$ in the context of the aftermath of Native-newcomer encounters. In this system Pocahontas is part of the Virgin and Princess binary because she was a 'good Indian' for helping the white man and saving John Smith (as Smith more or less successfully made people in England believe). This helps to explain the images that make her appear to be a positive figure by portraying her with lighter skin, aligning her with the culture she helped to assist. ${ }^{48}$ La Malinche is also whitened in many depictions, but these images carry negative connotations and reinforce the model of La Malinche as a traitor.

With regards to biblical imagery, Pocahontas has been compared with Rebekah, mother of Jacob and Esau who were white- and red-skinned respectively, symbolizing that Pocahontas is a mother figure to both nations. ${ }^{49}$ Further, she is seen as a symbol of cooperation between the two races, and thus has been called the "patron saint of secular America." ${ }^{50}$ Recall that La Malinche, too, in her capacity as a mother is considered by many to be the mother of mestizo Mexico. Interestingly, despite the fact that they both bore the children with white men, it is considered admirable in the case of Pocahontas but degrading in the context of La Malinche. Reasons for this will be examined in the final section of this paper.

Pocahontas's purity has often also been used as a parallel for the untouched American frontier and as a result, her later conversion to Christianity and assimilation into English society have been understood as a shift from wilderness to civility and represent the acceptance of European civilization and superiority. ${ }^{51}$ She is hailed as a heroine for authoring the redemption story of America and, as such a unique figure in American history, was often appealed to by independence fighters during and after the American Revolution. As the Thirteen Colonies struggled for liberation, they discovered that taking ownership of the Pocahontas story, especially the version that emphasized her motherhood, served to "free

\footnotetext{
47 Scully, "Indigenous Women and Myth Models," paragraph 13.

48 Downs, "Mirrored Archetypes," 703.

49 lbid, 411

${ }^{50}$ Scully, "Indigenous Women and Myth Models," paragraph 23.

${ }^{51}$ Downs, "Mirrored Archetypes," 402.
} 
[them] from the yoke of the mother country: ${ }^{\prime \prime 2}$ by having a mother in the New World, they could justify separating from the mother of the Old. Likewise, after the Revolution, the newly created Union sought to forge its own national and historic identity ${ }^{53}$ and it made perfect sense to once again call upon the mother who delivered them from the Old World, figuratively speaking.

Pocahontas was once again recreated in the mid-nineteenth century, where the romantic interpretation of her story comes to the fore. English professor Rebecca Mark particularly notes the significance of the resurgence of the Pocahontas narrative in the decades leading up to Civil War. She argues that, with the publication of John Davis's Travels of Four Years and Half in the United States in 1804, the romance narrative, which is immediately recognizable to us today, emerged. In Mark's explication, the reason for the newfound interest in Pocahontas has little to do with the search for 'true fact' and instead everything to do with the struggle between states for validation. Jamestown, Virginia looked to the famous Pocahontas/John Smith story in search for justification of its institutions and values, and in doing so 'uncovered' an "ersatz Pocahontas myth." ${ }^{\prime \prime 4}$ Outside of Virginia itself, states in both the North and South used Pocahontas as a symbol to promote their cause, based on the distinct set of American values each side developed in support of their interests. ${ }^{55}$ In the end, we can be left with no doubt regarding the pliable nature of Pocahontas's story.

In many respects Pocahontas and La Malinche are strikingly similar. For example, they both have come to occupy significant roles as mother figures in the histories of the United States and Mexico, respectively. However, we have also seen that in spite of their similarities, there are substantial differences underlying the way these Indigenous figures have been remembered and mythologized. It is important to examine the considerable differences that exist in our assessment of the two women, admitting the close resemblance their experiences share.

\section{Pocahontas and La Malinche: Mirror Images or Antithetical Archetypes?}

La Malinche and Pocahontas led analogous lives: the events for which they were remembered Pocahontas's encounter with John Smith and La Malinche's participation in Cortés's expedition took place in their youth. They aided the European newcomers to their land, married them, and mothered their children. They also died of European diseases when they were young, having led short but momentous lives and leaving powerful, complicated legacies that their nations are grappling with today.

In answer to the difference of Pocahontas's and La Malinche's legacies, one interpretation looks at the way in which Native-newcomer relations in general have been viewed in the United States and Mexico, which itself is a function of how each country tells its history. As Ziauddin Sardar succinctly puts it, "new history stops historical narrative at the point convenient to its own ideological needs. ${ }^{1{ }^{56}}$ Specifically, the answer to the question of whether the Indigenous woman was remembered positively or negatively is related to the extent of the Europeans' 'success' in accomplishing their mission of colonization. In the sense it is being used here, success is simply a measure of the thoroughness of colonization.

As Frances Karttunen, a historian and Nahuatl linguist, argues, the exact point when the Mexicans overthrew the Spaniards in 1821 is the moment that La Malinche's status changed: "In a wink she was demoted from crucial interpreter and counsellor to lover and wily mistress of Cortés, traitor to her race, mother of mestizos."${ }^{157}$ At this time, the disapproving attitude towards her was born, and it has grown and become wedged in the Mexican imagination ever since.

Mexico today considers itself a mestizo nation, acknowledging and embracing its dual history of Spanish imperialism and Indigenous dispossession and colonization. The Indigenous history has been examined vis-à-vis La Malinche, but something more can be said about the colonial side of things. The nature of Spanish colonial rule was such that it imposed a highly centralized and hierarchical imperial structure. Thus, after Mexico's independence movement, the vast majority of peninsulares, the class of

\footnotetext{
52 Mark, "Pocahontas Fever," 63.

${ }^{53}$ Downs, "Mirrored Archetypes," 402.

${ }^{54}$ Mark, "Pocahontas Fever," 53.

${ }^{55}$ Downs, "Mirrored Archetypes," 400.
}

${ }^{56}$ Sardar, "Double Victimisation of Pocahontas," 20.

${ }^{57}$ Karttunen, “Rethinking La Malinche," 297. 
Spanish-born government officials and representatives, returned to Spain. In the wake of such drastic socio-cultural and ideological changes (to say nothing of the economic and political) following independence in 1821, Mexicans were faced with the task of reinterpreting the newlycreated nation's history in such a way that would fit with its ambitions for its future self - a nation among many in a world of blossoming, free, modern states - while continuing its own unique Mexican story. José Vasconcelos's early twentieth century landmark work, The Cosmic Race, is replete with this kind of transformative language. In it, he argues that Mexico's national identity is best understood as a country of mestizos that incorporates the best elements of the Iberian and American races. ${ }^{58}$

Because Mexicans came to adopt such an understanding of their Indigenous history in the context of their self-identity, La Malinche was painted as a highly sexualized figure and betrayer of her nation and people, and elaboration upon these ideas led to her present status as the epitome of feminine treachery. Several academics, including Karttunen and Kristina Downs, who specializes in folklore, have interpreted this sudden change in perspective by asserting that in the tumult characterizing the transition from conquest to post-conquest, a scapegoat was needed, ${ }^{59}$ and who could more easily serve as one than La Malinche, the "Indian woman who could not get enough of the white $\operatorname{man}^{\prime \prime}{ }^{60}$

More recently, the scholarly community has been striving to present a more nuanced history of La Malinche and attempting to understand her motives from viewpoints other than the androcentric and Eurocentric models. Sandra Messinger Cypess, a professor of Latin American literature, has explored La Malinche's many renditions, especially her representation as a mother, in much detail. She focuses much of her energy on trying to understand why there is such a seemingly huge disparity between historical fact and national imagery. As we have seen, La Malinche is widely remembered as Cortés' mistress, and condemned on account of it, yet she is known to have been sexually active with only two people: her husband Jaramillo and Cortés.

\footnotetext{
58 José Vasconcelos, "The Cosmic Race," in The

Mexico Reader, ed. Gilbert M. Jospher and

Timothy J. Henderson (Durham: Duke University Press, 2002), 18-19.

${ }^{59}$ Downs, "Mirrored Archetypes," 404

${ }^{60}$ Karttunen, "Rethinking La Malinche," 297
}

Furthermore, there is nothing in historical sources and records to suggest that La Malinche was ever associated with sexual proclivity during her life; she only received that designation through the aftereffects of the conquest. ${ }^{61}$ There is an anachronistic element to applying modern definitions and sensibilities to a time and environment that functioned under a completely different set of mores, expectations, and ideals.

Karttunen, Chicano studies professor Cordelia Candelaria, and historian Clara Sue Kidwell have brought forth the argument that La Malinche's actions were motivated by nothing but pure survival. It is integral to our study of Nativenewcomer relations - or any historical phenomenon, for that matter - first, to resist the temptation of assuming all Indigenous peoples were alike and had similar goals and ambitions, and second, to suspend applying our knowledge of the ensuing events and outcomes retrospectively. Candelaria argues that as La Malinche was possibly sold into slavery by her own people, she likely had no strong sense of attachment, let alone affection, to a community that treated her as they did. ${ }^{62}$ Karttunen argues something similar, adding that Mesoamerica was by no means a utopian civilization with a unified sense of ethnic loyalty or the Indigenous solidarity and homogeneity that is too often misapplied in a quick, crude reading of Indigenous history. ${ }^{63}$ Instead, she focuses on the lack of alternatives available to La Malinche. She was offered as a gift to Cortés; she did not join him willingly. It is irrational to expect that she could somehow escape him and orchestrate a mass movement to overthrow the Spaniards. In Karttunen's own words, "This is no love story, no tale of blind ambition and racial betrayal, no morality play. It is the record of a gifted woman in impossible circumstances carving out survival one day at a time." ${ }^{64}$

Similar factors and motivations have influenced popular perceptions of Pocahontas in the American mind, and historians have brought forth comparable historical theories explaining those perceptions. Recall that, following Smith's adoption, violence broke out between Powhatan and the Jamestown settlers with the former fighting an uphill battle against the growing colony, eventually resulting in the obliteration of the Powhatan people. As British imperialism in

\footnotetext{
${ }^{61}$ Cypess, “'Mother' Malinche," 16-17.

${ }^{62}$ Candelaria, "A Feminist Prototype," 6.

${ }^{63}$ Karttunen, "Rethinking La Malinche," 304.

64 Ibid, 312.
} 
North America grew, and the one colony became many colonies, a number of differences between British and Spanish colonial rule in the Americas also became apparent. Most important to our understanding of Pocahontas is that, in contrast to the highly centralized and imposed imperial system of colonial Mexico, the Thirteen Colonies were home to a population which was, by the time of the American Revolution, made up of descendants of Englishmen who had become ideologically divorced from their counterparts in England.

Reflecting on these two circumstances - first, the decimation of Indigenous people in America and, second, an intellectual history that had evolved through the generations of English settlers in the Colonies to become, by 1765 , sufficiently at variance with English people living in England - it is no mystery that the collective consciousness of U.S. citizens today does not consider itself a mixed race nation as Mexico's does. It is certainly easier to understand why Pocahontas enjoys a relatively spotless reputation as one of America's earliest heroines and why her legacy is far less complicated and ambiguous compared to the notoriously complex and evasive one that La Malinche's story has left behind.

Unfortunately for Pocahontas, being remembered in a relatively more positive light is not the same as being remembered truthfully. As Sardar puts it, "[f]or all that [Americans] make her an icon, they are not telling her history. ${ }^{\prime 65}$ At the same time as we are striving to pick apart her legendary life, then, we cannot lose sight of the human component in our narratives of Pocahontas. The uncertainty and misunderstanding surrounding the ceremony where Pocahontas first met John Smith have been outlined above. This debate demonstrates a theme that we have just seen with La Malinche: Pocahontas's actions were determined for pragmatic reasons. They did not arise from romance, passion, or melodrama. In the case of Pocahontas, this is even truer if we consider her 'intervention' was likely part of a role she was assigned and carried out without fully realizing the significance and implications of the ritual itself.

Rayna Green's Pocahontas perplex becomes much less perplexing when we take into account the fact that Indigenous women are remembered according to the group that survives long enough to tell their story. The same sentiments are echoed by Downs, Kidwell, and women and

${ }^{65}$ Sardar, "Double Victimisation of Pocahontas," gender studies professor Pamela Scully. Additionally, if we recall Mark's recent work on Pocahontas in conjunction with this fact, it is not surprising that so little would be said and written from the perspective of Indigenous communities, much less Indigenous women. In fact, that scholars today debate the reliability of oral histories ${ }^{66}$ and their place in the academic realm is a measure of the thoroughness of colonization. Part of the legacy of colonialism is not simply the erasure of Indigenous title to life, land and livelihood, but Indigenous title to memory.

\section{Conclusions}

Asking the question "Who authored Indigenous history (if not Indigenous peoples themselves)?" is akin to asking "Who survived long enough to (re)tell the story?" In the case of the United States, Pocahontas is remembered positively not simply because she aided the white man, but because she aided the white man and the white man won. If not for the fact that the Jamestown colonists colonized as profoundly as they did, it is quite possible that Pocahontas would share a reputation as infamous as La Malinche's. We can only speculate. One certainty evidenced in the historical record is that the way in which these women are remembered says less about their actions in themselves than it does about the lasting significance of events that came after them - events they influenced, but did not control.

Without a doubt, Pocahontas's and La Malinche's lives and experience mirrored one another. Yet, their memories are antithetical due to the events that followed in the Nativenewcomer tale of which they were a part. La Malinche is regarded unfavourably not directly as a result of her actions - she acted identically to Pocahontas in many respects - but because she aided the Spanish and the Spanish were integrated into, but did not take-over, postindependence Mexican thought, demography, culture and society. Pocahontas aided the English (or was thought to have done so), and when the dust settled, the settlers were more or less the only ones left standing. In direct opposition to the conventional tales of Pocahontas and La Malinche, nothing in a historical reading of the events in their lives provokes any sense of inevitability or 'manifest destiny.' The women, for their part, were simply acting out of a mix of necessity, doubt, and fear during unpredictable

66 Mark, “Pocahontas Fever," 71. 
times. As young, powerful Indigenous women, their choices would usher in an era of memory, legend, and misrepresentation that reflects the centuries following conquest and colonization more so than their personal convictions and motivations as individuals.

\section{Bibliography}

Canderalia, Cordelia. "La Malinche: A Feminist Prototype." Frontiers: A Journal of Women Studies 5, 2 (1980): 1-6.

Cortés, Hernan. Hernan Cortés to Emperor Carlos V., 1522. In Hernan Cortés: Letters from Mexico. Translated and edited by Anthony Pagden, 72-74. New Haven and London: Yale University Press, 1986.

Cypess, Sandra M. "'Mother' Malinche and Allegories of Gender, Ethnicity and National Identity in Mexico," in Feminism, Nation and Myth: La Malinche, edited by Amanda N. Harris and Ronaldo Romero. Houston: Arte Publico Press, 2005.

Díaz del Castillo, Bernal. The Discovery and Conquest of Mexico, 1517-1521, 1585. Translated by A. P. Maudsley. New York: The Noonday Press, 1965.

Downs, Kristina. "Mirrored Archetypes: The Contrasting Cultural Roles of La Malinche and Pocahontas." Western Folklore 67, 4 (2008): 397-414.

Green, Rayna. "The Pocahontas Perplex: The Image of Indian Women in American Culture." The Massachusetts Review 16, 4 (1975): 698-714.

Karttunen, Frances. "Rethinking La Malinche." In Indian Women of Early Mexico, edited by Susan Schroeder, Stephanie Wood and
Robert Haskett, 291-312. Norman: University of Oklahoma Press, 1999.

Kidwell, Clara S. "Indian Women as Cultural Mediators." Ethnohistory 39, 2 (1992):97-107. Kidwell, Clara S. "What Would Pocahontas Think Now? Women and Cultural Persistence." Callaloo 17, 1 (1994): 149-159.

Mark, Rebecca. "Pocahontas Fever," in Ersatz America: Hidden Traces, Graphic Texts and the Meaning of Democracy. Charlottesville: University of Virginia Press, 2014 .

Rountree, Helen. Pocahontas, Powhatan, and Opechancanough: Three Indian Lives Changed by Jamestown. Charlottesville: University of Virginia Press, 2005.

Sardar, Ziauddin. "Walt Disney and the Double Victimisation of Pocahontas." Third Text 10, 37 (1996): 17-26.

Scully, Pamela. "Malintzin, Pocahontas, and Krotoa: Indigenous Women and Myth Models of the Atlantic World." Journal of Colonialism and Colonial History 6, 3 (2005): 1-28.

Smith, John. The Generall Historie of Virginia, New England, and the Summer Isles. London: I.D. and I. H., 1632 .

The Making of Pocahontas. Dir. Dan Booth. Laserdisc. Walt Disney Corporation, 1995.

Townsend, Camilla. Pocahontas and the Powhatan Dilemma. New York: Hill and Wang, 2004.

Vasconcelos, José. "The Cosmic Race." In The Mexico Reader, edited by Gilbert M. Joseph and Timothy J. Henderson, 15-19. Durham: Duke University Press, 2002. 